\title{
Realization of politeness in Ermato Tolantang Sansai novel
}

\author{
Roy Ismail ${ }^{1}$, Nurizati ${ }^{2}$, Winda Azmi ${ }^{3}$, Witra Amelia ${ }^{4}$ \\ \{ student.unp.ac.id ${ }^{1}$, nurizzati2138@ fbs.unp.ac.id ${ }^{2}$, windaazmy1991@ gmail.com ${ }^{3}$ \\ witraamelia@student.unp.ac.id $\left.{ }^{3}\right\}$ \\ 1,2,3,4 Universitas Negeri Padang, Jl. Prof. Dr. Hamka Air Tawar Padang Sumatera Barat 25131, \\ Indonesia
}

\begin{abstract}
The purpose of this study is to provide a description of the realization of politeness in Ermanto Tolantang's novel Sansai in expressing the principle of courtesy in the use of language. This research is a qualitative descriptive study which is the object of this research is a form of speech in the form of the polite maxim in the novel Sansai by Ermanto Tolantang. Collecting data in this study by grouping using polite maximal analysis tables. The results of the discussion can be concluded that the realization of politeness in the novel Sansai by Ermanto Tolantang uses the principle of courtesy, namely Maximum Wisdom (Tact Maxim) totaling twelve data, Generosity Maxim totaling eight data, Appreciation Maxim seven data, Maxims of modesty seven data, Maximum praise of seven (Data) hearts (Modesty Maxim) nine data Maksim agreement (Agreement Maxim) sixteen data and Maksim sympathy (Sympathy Maxim) eleven data. So the data most often found in the realization of politeness in Ermanto Tolantang's Sansai novel is an agreement maxim. This result shows the use of courtesy in 63 Ermanto Tolantang's novels of Sansai and is included in the "good enough".
\end{abstract}

Keywords:Realization, politeness, and Sansai novel

\section{Introduction}

The poverty experienced by Emak Naimah's family and her daughter Berlian in the coastal village, Negeri Sepuluh Nation. The longer life sansai when his father left his famous triggers went to neighboring Malaysia. In addition, Diamond's house and land must be executed by the court and expelled immediately from the coastal village. The living conditions that sansai has, the family of Buya Bahar sincerely invites Berlian and Emak Naimah to ensure his love for a village girl named Nurlela, the son of Buya Bahar, whom he has long desired. To change his destiny and to improve his dignity and life, Berlian decided to migrate and replace Nurlela to anchor their love into a more serious relationship, namely in marriage. Mother of Diamonds is entrusted so that in Perantuana look for relatives from Pariaman because Grandma Berlian has also been driven out of her home country. As for the conflict that was violated by the Berlian family, it had to be expelled from Pariaman and Negeri Sepuluh Nation.

Research on politeness in language has been carried out in various countries. A number of literature reviews were conducted, research on language politeness was conducted by. Research conducted by [2]) in Thailand reveals that someone who asks politely will tend to get polite answers to the questions they ask. These findings support the statement [3] in Canada. [3] found that choosing the right way of speaking can build solidarity in communication. Based on this, it is suspected that the speech partner can be polite in the language, of course, the speaker who starts the conversation must be polite in the language first. In Indonesia, [4] examined the object of major studies as revealing the style of language, types of speech acts, speech strategies and politeness principles as well as the level of 
politeness contained in the DKI Jakarta club and cawagub debates. [5] examine the object of question and answer speech from the presenter and resource persons in the Mata program.

Based on the description that has been explained, the discussion that will be examined in this article is how the realization of politeness in Ermanto Tolantang Novel Sansai. This study aims to describe, analyze and interpret in a detailed and systematic form of politeness in Ermanto Tolantang's Novel Sansai.

\section{Method}

This research was conducted in Padang, and the process for conducting this research was carried out in stages. When this research began on August 12, 2018. This research was included in a qualitative descriptive form. Descriptive means research carried out solely based on facts or phenomena that are empirically alive to the speaker. This qualitative research aims to produce descriptive data in the form of politeness in the Sansai novel by Ermanto Tolantang. [6] defines qualitative methodology as a research procedure that produces descriptive data in the form of spoken words from people and observed behavior. The data in this study are the use of oral discussion in the Sansai novel by Ermanto Tolantang that uses the principle of courtesy. The data of this study are utterances or sentences that contain elements of the principle of courtesy by grouping them using a maximal courtesy analysis table.

\section{Result and discussion}

This study examines the realization of politeness in the Sansai novel by Ermanto Tolantang using the principle of courtesy.The realization of politeness in Ermanto Tolantang's Sansai novel uses the principle of courtesy, namely the Maximum Wisdom (Tact Maxim) of twelve data, Generosity Maxim totaling eight data, the seven Data Maximization (Approbation Maxim), The Maximum Humility (Modesty Maxim) nine data, the maximal agreement (Agreement Maxim) sixteen data and the Max Sympathy (Sympathy Maxim) eleven data. So the data most often found in the realization of politeness in the novel of Sansai Karya Ermanto Tolantang is the maxim of agreement. This result shows the use of the principle of courtesy in the Sansai novel by Ermanto Tolantang as many as 63 utterances and included in the criteria of "quite good".

To make it easier to understand the use of politeness principles in Ermanto Tolantang's novel sansai presented in table 1 .

Table 1. The use of the principle of good manners in Ermanto Tolantang sansai novel

\begin{tabular}{llll}
\hline Number & Politeness & Data & Precentage \\
\hline 1 & Obey & 63 & $63 \%$ \\
& a. Tact Maxim & 12 & $19,0 \%$ \\
b. Generosity Maxim & 8 & $12,6 \%$ \\
c. Approbation Maxim & 7 & $11,1 \%$ \\
d. Modesty Maxim & 9 & $14,2 \%$ \\
e. Maxim Agreement & 16 & $25,3 \%$ \\
f. Sympathy Maxim & 11 & $17,4 \%$ \\
\hline
\end{tabular}




\subsection{Tact Maxim}

[7], the wisdom maxim has the following characteristics: (a) make the loss of others as small as possible, and (b) make the benefit of others as much as possible. The purpose of the maxims above is to always reduce one's own profit and maximize the profits of others in speaking activities. [8] explains that the maxim of wisdom in the principle of politeness is that the speaking participants should hold to the principle of always reducing their own profits and maximizing the profits of others in speaking activities.

Speech: " Apakah pantas Ananda tinggal dirumah Pak Haji? Bagi Ananda tinggal di Masjid Annur beberapa minggu ini sudah layak Pak Haji".

Not far from Jao Village, Aisyah and Mother Aisyah had cleaned up at the pavilion and had asked Bapak to invite Berlian. Based on the speech above, the speaker has obeyed the wisdom maxim because Hajj Amran was so wise and cared about Berlian. Mr. Haji Amran tried to persuade Berlian to accept the request of Aisha and Mother of Aisha. Not beautiful to reject the kindness of Mother and Aaisyah.

\subsection{Generosity Maxim}

A maxim of generosity or maxim of generosity, participants in speech are expected to be able to respect others. Respect for others will occur if people can reduce profits for themselves and maximize profits for other parties.

Speech: " Nak Berlian, kalau memang ingin mengadu untung di kampung jao ini, silahkan nanti pukul tujuh ke toko Bapakya".

At that time Berlian Koto prayed at the Annur Mosque and met with Haji Amran to work for his character. It is as if the answer to the long and solemn Diamond Koto prayer was earlier. Based on the example above, I have complied with the maxim of generosity because Haji Amran, who at that time heard Berlian's prayer was so solemn. At that time Berlian Koto prayed fully to the Creator and ruler of Nature. Haji Amran, who was also after the morning prayer, was stunned to pay attention to the village man in the corner of the mosque. looks seriousness of the young child. the more convinced Haji Amran's heart to help Berlian Koto's life.

\subsection{Approbation Maxim}

[8] Explaining that the maxim of appreciation or maxim of praise is said that people will be considered polite if in speaking they always try to give appreciation to other parties. With this maxim, it is hoped that the participants of the speech will not mock one another, meaning each other, or demean each other. Speech participants who often denigrate other parties. Speech participants who often invite other speeches participants in speaking activities will be said to be rude. It is said so, because the act of mocking is an act of disrespect for others.

Speech: " Oleh karena kecantikan Nurlela itu, aku juga berhak untuk mendapatkannya. Sama halnya dengan Roni Caniago, aku juga mempunyai hak untuk mendekati Nurlela". 
Spoken by a young man named Berlian Koto who praised the beauty of the village girl Nurlela. The speech is a maxim of praise because Diamond Koto has physical beauty that is the beautiful cheeks of Nurlela like a sliced fruit using a catter knife that has just been used. Her cheeks are slightly reddish white. Above him there were eyebrows like ants accompanied by a regular line which had been prepared by troop commanders who lined up neatly. The oval white chin is like hanging to the ground that's Nurlela's beauty.

\subsection{Modesty Maxim}

[8] Explain that in the maxim of simplicity or maxim of humility, the speech participant is expected to be humble by reducing praise to himself. People will be said to be arrogant and proud when in speaking activities always praise and favor themselves.

Speech: "Kalau diurutkan silsilahnya dari Prabu Siliwangi. Berarti saya mewakili orang Sunda," kata Ma'ruf Amin (070/MA:09-04/ T1/TKN) “Emak, biarkanlah Berlian mengetahui semua ini. Berlian sudah besar Emak. Umur Berlian hampir lima belas tahun. Biarlah tidak ada harapan bagi Berlian untuk melanjutkan sekolah karena kemiskinan. Namun, untuk cercahan dan hinaan orang kampung selama ini tentang asal muasal Berlian telah pula menjadi persoalan dalam pemikiran”.

Mother's face is increasingly dim. Berlian Koto improves his sitting position. Koto diamonds moved slightly so that they approached Mother. Based on the speech above, the speaker has obeyed the maxim of humility, because Berlian Koto sincerely did not continue schooling due to the poverty conditions experienced, with a sad tone, with humility Berlian Koto asked permission from Mother to leave this village and decided to migrate to support her his family.

\subsection{Agreement Maxim}

[8] Explains that in the maxims of agreement it is often referred to as compatibility maxims. In this maxim, it is explained that the speech participants foster mutual compatibility or agreement in speaking activities.

Speech: " Buya Bahar sebagai kepala kampung yang kami hormati, kami sebagai juru sita atas nama pengadilan Negeri Mulia di Salido, kami mohon izin mengeksekusi rumah, sebagai kebun, dan sepiring sawah atas nama keadilan akan mengembalikan kepada yang punya hak yaitu keluarga besar Mak Uwo Hafsah, permohonan kepala juru sita pagi ini disaksikan oleh hampir seluruh penduduk kampung Pesisir. Silahkan, jika itu memang atas dasar kebenaran".

This speech was delivered by the chief bailiff, regarding the execution of the house, garden and land to the big family of Emak Uwo Hafsah. Based on the speech above, the speaker has complied with the maximum agreement because Buya Bahar as the village head has received approval from the bailiff. Please, if it is indeed based on the truth, with the command of the bailiff's head, move dozens of young men and claws bring down the wooden house which has also been tilted towards the Qibla, the doors are released. 


\subsection{Sympathy Maxim}

[8] Explain that in the maxim of sympathy, it is expected that the speech participants can maximize the attitude of sympathy between one party with another party. Snipipati attitude towards one of the speech participants will be considered as an act of impolite.

Speech: "Tabahkanlah hatimu, Nak Berlian. Sesungguhnya didalam kesulitan Allah akan hadirkan kemudahan dalam hidup kita, Nak. Yakinlah itu seyakin-yakinya, Nak ".

Spoken by mother Naimah with a stoic heart. Based on the example above, Naimah's mother had sympathy for her child, Berlian Koto, who at that time was hesitant in facing the problem of a house dispute. Berlian Koto, who has lived in the house for years with her mother, must leave the house tomorrow morning. Mother Naimah tries to give her sympathy to her child to remain patient and we leave all our life paths to the owner.Rest assured it is as much as possible.

This study complements the previous research conducted by Cahyaningrum which found that there was a maxim of wisdom maxim, simplicity maxim, consultation maxim, appreciation maxim, and sympathy maxim. The obedience of students' language politeness can be used as teaching material for Indonesian negotiation text material in High Schools.

\section{Conclusion}

Based on the results of the discussion it can be concluded that the realization of politeness in Ermanto Tolantang's Sansai novel uses the principle of courtesy, namely the Maximum Wisdom (Tact Maxim) amounting to twelve data, Generosity Maxim totaling eight data, Appreciation Maxim seven data, Maximum compliment seven humility (Modesty Maxim) nine data Maksim agreement (Agreement Maxim) sixteen data and Maksim sympathy (Sympathy Maxim) eleven data. So the data most often found in the realization of politeness in the novel of Sansai Karya Ermanto Tolantang is the maxim of agreement. These results indicate the use of the principle of courtesy in the Sansai novel by Ermanto Tolantang as many as 63 utterances and are included in the criteria that are "quite good". more deeply about the realization of this politeness.

The author thanks the supervisor who has taken the time to complete this article and the contributors who have provided criticism and suggestions for this article. the author hopes this research can contribute to further research and the authors also hope that with this research, it should be able to provide knowledge and understanding for readers about the realization of politeness in written form.

\section{Acknowledgements}

This article was realized thanks to help from various parties. The author would like to thank all parties who are willing to contribute data to this article. The author also thanked the Lecturer who has given criticism and suggestions for the perfection of this paper.

\section{References}

[1] Syahrul, R: Pragmatik kesantunan berbahasa (menyimak fenomena berbahasa indonesia guru dan siswa). Padang:: UNP Press. (2008) 
[2] Getkham, K:Politeness strategies in thai graduate research paper discussion: implications for second/foreign language academic writing. English Language Teaching, 7(11), 159-167. (2014)

[3] Salom, L.G. \& Monreal, C.S: Interacting with the reader: politeness strategies inengineering research article discussion. International Journal of English Studies, 175-189. (2009)

[4] Aziz. :Kesantunan berbahasa para pasangan calon dalam debat pilkada Dki Jakarta (kajian pragmatik).Tesis, Program Pascasarjana Universitas Negeri Padang. (2018)

[5] Yuni, Q.F. :Kesantunan berbahasa dalam Mata Najwa (tinjauan pragmatik). Nosi 1(7), 706-716. (2013)

[6] Moleong, Lexv J.: Metodologi penelitian kualitatif. Bandung: Remaja Rosdakarya. (2006)

[7] Leech, Geoffrey. :Prinsip-prinsip pragmatik. Jakarta: UI Press. (1983)

[8] Rahardi, Kunjana. :Pragmatik Kesantunan Imperatif Bahasa Indonesia. Jakarta: Erlangga. (2005)

[9] Cahyaningrum, F. : Kesantunan berbahasa siswa dalam konteks negosiasi di sekolah menengah atas. Jurnal Bahasa Indonesia, 4 (1)1-23. (2018)

[10] Ermanto, :Sansai. Padang. Visigraf. (2018) 